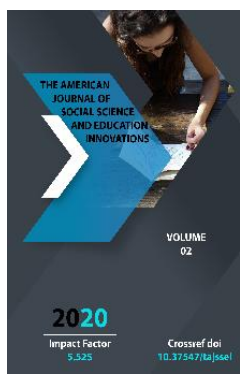

\title{
Oratory Genre In The Work Of Uzbek Composers
}

\author{
Sayyora Makhmudova \\ Senior Lecturer Of The Department Of Music Theory, State Conservatory Of Uzbekistan
}

Copyright: Original

content from this work may be used under the terms of the creative commons attributes 4.0 licence.

\section{ABSTRACT}

This article covers the characteristics of the oratorio genre, which is one of the major genres in professional music, the unique interpretation of this genre in the works of Uzbek composers, and the essence of the content of oratorios written in recent years.

\section{KEYWORDS}

Genre feature, literary content, dramaturgy, synthesis of genres.

\section{INTRODUCTION}

After the independence of our country, great attention was paid to the development of Uzbek music. Efforts in this direction pave the way for the development of our musical art. In particular, the resolution of the President Sh.M.Mirziyoev "On the organization of the Union of Composers and Composers of Uzbekistan" states: and special attention to the development of classical genres such as oratorio; One of the most pressing issues today is to focus on "expanding the opportunities and conditions for young composers, composers and musicologists, all performers to engage in creative work." From the above, it is clear that the attention paid to composers and composers in our country is growing. 


\section{THE MAIN RESULTS AND FINDINGS}

Oratorio is one of the major genres in professional music. An oratorio is a largescale work written for sukhandon, soloists, choir and symphony orchestra. The oratorio originated in the sixteenth and seventeenth centuries almost simultaneously with opera and cantata. The oratorio includes solo arias, recitatives, ensembles and choirs. The oratorio develops on the basis of a dramatic plot like an opera. But in it the narration of dramatic situations prevails. Another distinguishing feature is that it is characterized by a large scale of development on a larger scale and the accuracy of the selected plots. The first oratorios were based on the texts of the Bible and the Torah and were performed in churches.

This genre originally had its own different appearances, styles and evolved in different stages of European compositional creativity. The oratorio genre to this day has its own content, dramatic idea, and a certain form structure and performance style. This genre developed over the centuries and slowly began to appear in the works of Central Asian composers by the second half of the twentieth century. An example of this is the Kyrgyz composer AM Maldybaev "Words to Kyrgyztan" (1972), "Blooming city” (1979), "Party is our happiness" (1985), "Kyrgyztan" (1986) oratorios and K. Moldobasanov "Mother's Field" (1975) ballet oratorios. Among the Kazakh composers is G. Jumanova "Charge over the steppe", "Tatiana's letter" such as oratorios.

In the composition of our country, this genre has also gone through a unique path of development. Mukhtar Ashrafi's epic oratorio "The Epic of Rustam" is close to the classical genre. The oratorio is based on the epic "Shakhnoma" by Abdulkasim Firdavsi. The plot of the work reflects the love of Tahmina and Rustam, the courage of young Sukhrob, the tragedy of a father and son.
Continuing the tradition of the genre, the central scenes were performed by the choir, showing the changing intensity of the experiences that evoke deep thought in the work. Oratorio music is rich in bright tones, it contains the principles of development specific to the status, which has been studied in the work of musicologists.

If we pay attention to the works of the famous composer Ikrom Akbarov. He has oratorios "Tashkentnoma" (1964), "Eternal memory" (1985) and "Naqshbandiya" (2003). The composer's first oratorios mainly sang about the history of our country, the memory of our great ancestors, the nature and beauty of our country. One of the last works of the composer is the oratorio "Naqshbandiya". The oratorio is based on a religious theme and embodies the image of Hazrat Bahauddin Naqshband, the founder of Sufism.

The oratorio genre also has a special place in the work of Felix Yanov-Yanovsky. His "The Voice" (1968) and "The Tale of Chile" (1977) There are oratorios. Composer's "The Voice" his oratorio, from beginning to end, is reminiscent of the millions of people who perished in the Hiroshima tragedy in the name of the "human voice". "The Tale of Chile" and in his oratorio, it tells the story of the Chilean people who went through a difficult ordeal. Both oratorios reflect the trials of human destiny and the struggle for freedom [7].

The oratorio genre also has a special place in the work of Habibulla Rakhimov. His "Auschwitz" (1974), The oratorios "Bahouddin Balogardon" (1993), "Sahibqiron abadiyati” (1996), "Istiqlol” (1998) were warmly received by professional music lovers. Habibulla Rakhimov's oratorios are diverse in content. It is known from the range of selected themes that the composer has touched on themes that can embody the features of this genre. 
Mustafa Bafoev is also a prolific composer in the oratorio genre. The composer has oratorios "Bukhoronoma" (1978), "Song about Tashkent" (1983), "Tears of Roxana" (1987), “Hajnoma” (1993), “Etti pir” (2018).

Among Uzbek composers, Mustafa Bafoev was one of the first to create religious works with a religious content through the oratorio "Hajnoma". The orthography "Hajnoma", written among the first, was warmly received by music lovers. Creating works on a religious theme requires a high level of responsibility from the composer. The reason is that in order to write music, the content of the text chosen for it must be real, well thought out. The oratorio written in the words of Abdulla Aripov gave a great impetus to the further development of this genre in composition. This oratorio of Mustafa Bafoev is dedicated to the memory of "Hazrati risolatpanoh, Mammad Mustafa sallallahu vasallam." The oratorio is a series of six parts, each of which is written on a programmatic basis. The oratorio is written for suhandon, soloists (metstso soprano, tenor, baritone), choir and orchestra. The oratorio consists of the following sections: "Kabatullah", "Mother", "Surahs of the Qur'an", "Hojilar", "Ibrat", "Paygambar". The parts of the oratorio are based on the sequence of the historical process.

In recent years, the composer's oratorio "Yetti Pir" has appealed to music lovers. The idea to write this oratorio arose after the composer's visit to the "Yetti Pir". Mustafa Bafoev has been collaborating with the poet Shodmon Suleyman for several years. In writing this work, the composer turned to the poet Shodmon Suleiman.

"Yetti Pir" the oratorio was written for sukhandon, solo choir and symphony orchestra. "Yetti Pir" his figures are brilliant representatives of the teachings of Sufism. Leaders of mystical teachings such as "Hazrat Abdulhaliq Gijduvani”, "Hazrat Haji Revgari”, "Hazrat Khoja Mahmud Anjir Fagnavi",
"Hazrat Ali Romitani”, "Hazrat Bobo Samosi", "Hazrat Sayyid Mir Kulol" and "Hazrat Bahauddin Balogardon" dedicated to the piers. The work is rich in the tones of the ancient land of Bukhara. Because the play does not have a dramaturgy that covers a wide range of events. Visitors to the shrine are portrayed as the protagonist of the work.

The oratorios that reflect the ideas glorifying our country in terms of content are Mirhalil Mahmudov's "Tashkent sadosi" (1974) and Sulaymon Yudakov's "Galaba" (1975).

\section{RESULT}

As a result of the synthesis of the oratorio genre with other major genres, he created such creative products as opera oratorio, ballet oratorio, rock oratorio. Examples are Rustam Abdullayev's ballet oratorio "Shoshma Quyosh" (1987), Dilorom Saidaminova's rock oratorio "Senga vatanim" (1985), and Mustafa Bafoev's ballet oratorio "Zoroastrianism" (1995). The interest in the oratorio genre in the works of young composers of today has not diminished. An example of this is the opera oratorio "The Road to Heaven" by a young talented composer Nurali Erkaev (2017). The oratorio is based on Abdulla Aripov's dramatic epic of the same name. The work consists of curtains called "Libra", "Father", "Mother" and "Friend". The play tells the story of doing good to people in this fanciful world, the loyalty, kindness and generosity of two friends. The opera-oratorio was also warmly received by the audience and attracted the attention of young musicologists to the genre.

\section{CONCLUSION}

In the works of Uzbek composers, the oratorio genre has undergone a unique process of development. It would be a bit far from the truth to say that all of the oratorios listed above have been successful. Literary content plays an important role in the creation of an oratorio and its successful 
performance. As in any genre, dramaturgy is important in oratorio. At the same time, first of all, it is necessary to take into account the relevance, importance and educational aspects of the appropriate literary content and theme. While the first oratorios of Uzbek composers focused on the glorification of the homeland and historical figures, after the period of independence more oratorios on religious themes began to appear. However, there are some shortcomings in oratorios. For example, the lack of national spirit in the performance of oratorios, the problem of the choir, the problems of the orchestra, the performance after the creation of the oratorio and its application to the general public. These issues have not lost their relevance before and now. We hope that young composers will take into account the above shortcomings and create new works.

\section{REFERENCES}

1. Asafiev. B.V. Musical form as a process L., 1971

2. Analysis of vocal works. / Kolovskiy O.P. edited by L., 1998.

3. Akbarov I.A. Dictionary of Music. Publishing House of Literature and Art named after G. Gulom. T., 1987y.

4. Bafoev M. "Ruboiyot and compositional creativity" T., 2008.

5. Jabborov A, Begmatov S, Azamova M. History of Uzbek music. T., 2018.

6. Jabborov.A. "Composers and musicologists of Uzbekistan". T.. 2004 y.

7. History of Uzbek Soviet music. T., 1972 I vol.

8. History of Uzbek Soviet music. T., 1973 II vol.

9. History of Uzbek Soviet music. T., 1991 III vol.

10. Musical encyclopedia. M., 1973-1982. 